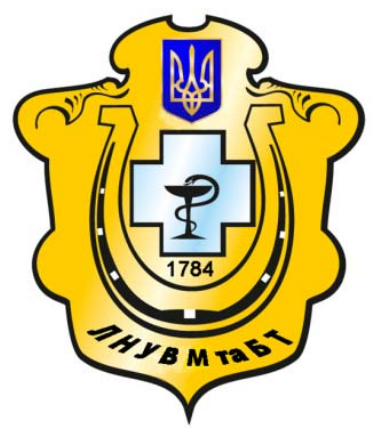

Науковий вісник Львівського національного університету ветеринарної медицини та біотехнологій імені С.3. Гжицького

Scientific Messenger of Lviv National University of Veterinary Medicine and Biotechnologies named after S.Z. Gzhytskyj

doi:10.15421/nvlvet7119

ISSN 2413-5550 print

ISSN 2518-1327 online

$\underline{\text { http://nvlvet.com.ua/ }}$

УДК 619:616:619:615.9

\title{
Вміст мікроелементів в сироватці крові тільних корів різних біогеохімічних провінцій
}

\author{
В.В. Саулко \\ semex@ukr.net \\ Національний університет біоресурсів і природокористування Украӥни, \\ вул. Героїв Оборони, 11, м. Київ, 03041, Україна
}

\begin{abstract}
В статті наведені данні щодо вмісту окремих мікроелементів у сироватці крові клінічно здорових та із ознаками мікроелементозів тільних корів із різних біогеохімічних провінцій. Вміст окремих мікроелементів у сироватиі крові клінічно здорових тільних корів із різних біогеохімічних провінцій істотно різниться, однак, знаходиться у фізіологічних межах. $B$ умовах біогеохімічної провіниії Тернопільської області встановлено зниження вмісту Йоду та Цинку в сироватиі крові корів на 2 - 23\% відповідно до показників у тварин південно-східних провінцій Дніпропетровської, Сумської, Миколаївської та Донецької областей. У сироватиі крові тварин біогеохімічної провіниії Сумської області найнижчий вміст Купруму, Мангану та Кобальту. Грунти північно-східних біогеохімічних провінцій очевидно більш насичені даними мікроелементами, що випливає із вищого їх вмісту у сироватиі крові корів, однак, дані теж не однорідні. У сироватиі крові корів біогеохімічної провіниії Дніпропетровської області нижче вміст Йоду, Купруму та Кобальту при вищому вмісті Цинку та Мангану у порівнянні із показниками тварин із біогеохімічних провінцій Миколаївської та Донецької області.

Встановлено достовірне зниження вмісту Йоду, Купруму, Мангану, Кобальту та Цинку в сироватиі крові тварин $з$ ознаками мікроелементозів різних біогеохімічних провінцій. Так, вміст Йоду в сироватці крові тварин з ознаками мікроелементозів був на 16 - 24\%, Цинку на 17 - 29, Купруму на 22,6 - 41,1\%, Кобальту на 2,4 - 51\% та Мангану на 25 - $41 \%$ нижче від показників клінічно здорових тварин.
\end{abstract}

Ключові слова: Йод, Купрум, Манган, Кобальт, Цинку, корови, мікрроелементози, біогеохімічні провінції.

\section{Содержание микроэлементов в сыворотке крови стельных коров разных биогеохимических провинций}

\author{
В.В. Саулко \\ semex@ukr.net \\ Национальный университет биоресурсов и природопользования Украины, \\ ул. Героев Обороны, 11, Киев, 03041, Украина
}

В статье приведены данные по содержанию отдельных микроэлементов в сыворотке крови клинически здоровых и с признаками микроэлементозов стельных коров из разных биогеохимических провинций. Содержсание отдельных микроэлементов в сыворотке крови клинически здоровых тельных коров из разных биогеохимических провинций существенно отличается, однако, находится в физиологических пределах. В условиях биогеохимической провиниии Тернопольской области установлено снижение содержания йода и иинка в сыворотке крови коров на $2-23 \%$ в соответствии с показателями у животных юго-восточных провиниий Днепропетровской, Сумской, Николаевской и Донеикой областей. В сыворотке крови животных биогеохимической провинции Сумской области низкое содержание меди, марганца и кобальта. Почвы северовосточных биогеохимических провиниий, очевидно более насыщенные данными микроэлементами, что следует из высшего их содержания в сыворотке крови коров, однако, данные также не однородны. В сыворотке крови коров биогеохимической провинции Днепропетровской области ниже содержание йода, меди и кобальта при высоком содержании ичинка и маргания по сравнению с показателями животных с биогеохимических провинций Николаевской и Донецкой области.

Citation:

Saulko, V. (2016). Trace elements in serum calf cows of various biogeochemical provinces. Scientific Messenger LNUVMBT named after S.Z. Gzhytskyj, 18, 3(71), 83-86. 
Установлено достоверное снижение содержания йода, меди, марганца, кобальта и ичина в сыворотке крови животных с признаками микроэлементозов различных биогеохимических провинций. Так, содержание йода в сыворотке крови животных с признаками микроэлементозов было на 16 - 24\%, цинка на 17 - 29\%, меди на 22,6 - 41,1\%, кобальта на 2,4 51\% и марганціа на 25 - 41\% ниже показателей клинически здоровых животных.

Ключевые слова: йод, медь, марганец, кобальт, цүинка, коровы, микрроелементозы, биогеохимические провинции.

\title{
Trace elements in serum calf cows of various biogeochemical provinces
}

\author{
V. Saulko \\ semex@ukr.net \\ National University of life and environmental sciences of Ukraine, \\ Heroyiv Oborony Str., 11, Kyiv, 03041, Ukraine
}

\begin{abstract}
The article presents data on the content of certain trace elements in the blood serum of healthy and signs of micronutrient malnutrition calf cows from different biogeochemical provinces. The content of certain trace elements in the blood serum of healthy calf cows from different biogeochemical provinces varies significantly, however, is in the physiological range. In terms of biogeochemical province Ternopil region set reduction iodine and zinc in serum of cows at $2-23 \%$ to reflect the animal's south-eastern provinces of Dnipropetrovsk, Sumy, Nikolaev and Donetsk regions. Serum animal's biogeochemical province Sumy Oblast lowest content of copper, manganese and cobalt. Soils northeastern provinces biogeochemical obviously richer data micronutrients, resulting from the higher their content in blood serum of cows, however, the data is also not homogeneous. Serum cow's biogeochemical province Dnipropetrovsk region below iodine, copper and cobalt at higher zinc and manganese compared to the figures of animal's biogeochemical provinces Mykolayiv and Donetsk region. Even in clinically healthy cows of the experimental farms zinc in serum rather low $(14.8-17.4 \mathrm{mmol} / \mathrm{l})$. In animals with signs of disease on the lack of trace elements zinc in serum is lower at $17-29 \%(r \leq 0.05-$ 0.01) from healthy animals. Moreover, lowest zinc in the blood serum of animal's biogeochemical province Ternopil region.

In clinically healthy animals with biogeochemical province Dnipropetrovsk region manganese content in serum is the highest $(4.10 \pm 0.15 \mathrm{mmol} / \mathrm{l})$, and even in animals with clinical signs of the disease was not significantly changed, whereas in animals from other provinces manganese content within $1.96-2.32 \mathrm{mmol} / \mathrm{l}$, respectively $25-41 \%(r \leq 0.01-0.001)$ below that of the clinically healthy animals in respective farms. The authentic reduction iodine, copper, manganese, cobalt and zinc in serum of animals with signs lack micronutrients different biogeochemical provinces. Thus, the iodine content in the blood serum of animals with signs lack micronutrients was at $16-24 \%$ Zinc at 17-29, on 22.6-41.1\% copper, cobalt to manganese and $2.4-51 \%$ to $25-41 \%$ below that of the clinically healthy animals.
\end{abstract}

Key words: iodine, copper, manganese, cobalt, zinc, cows, biogeochemical province.

\section{Ветуп}

Збереження здоров’я тварин, підвищення їх продуктивності та отримання життєздатного потомства неможливе без забезпечення оптимального рівня мінерального живлення (Klicenko et al., 2001). Нестача або надлишок окремих макро- і мікроелементів у раціоні тварин призводять до зниження продуктивності та резистентності організму. Мінеральні елементи, які надходять із кормами в організмі включаються в структурні елементи клітин і тканин, беруть участь у метаболічних реакціях, входять до складу багатьох ферментів, $\epsilon$ їх активаторами, а тому відіграють важливу роль у обміні речовин (Avcyn et al., 1991).

За наявністю рухомих форм мікроелементів у грунтах всю територію України поділяють на чотири геохімічні зони: західну, північно-східну, центральну і південну. Грунти західної геохімічної зони характеризуються дефіцитом I, Co, Zn, Mn і в окремих місцях $\mathrm{Cu}$. У грунтах північно-східної геохімічної зони виявлено дефіцит рухомих форм Co, Zn, а в окремих місцях - Mn i Cu. Е У грунтах центральної геохімічної зони дещо краще забезпечені мікроелементами, однак тут виявлено дефіцит $\mathrm{Zn}, \mathrm{Co}$, а в окремих місцях надлишок Mn i B (Sudakov et al., 1991; Levchenko et al., 2002).

Основними кормами великої рогатої худоби в господарствах є корма власного виробництва. У той же час грунти і вода, а в результаті і рослинні корми окремих біогеохімічних провінцій, як було відмічено, недостатньо забезпечені деякими мікроелементами (Georgievskij et al., 1979; Kondrahin, 1989). Більшість тварин адаптується до недостачі або надлишку мікроелементів, однак у них спостерігається зниження продуктивності. У інших тварин виникають клінічні прояви мікроелементозів.

Виходячи із вищенаведеного, наукову актуальність становлять комплексні дослідження щодо визначення вмісту біогенних мікроелементів у сироватці крові тварин, за вмістом яких можна діагностувати ці захворювання і виявляти відповідні біогеохімічні провінції.

Мета досліджень - дослідити вміст Йоду, Купруму, Мангану, Кобальту та Цинку в сироватці крові тільних корів різних біогеохімічних провінцій.

\section{Матеріал і методи досліджень}

Робота виконувалась упродовж 2015 - 2016 рр. на кафедрі фізіології, патофізіології та імунології Національного університету біоресурсів і природокористування України.

Для виконання даної мети було проведено п'ять серій досліджень в господарствах різних біогеохімічних провінцій України, зокрема: I дослід - у ТзОВ «Україна», с. Скорики Підволочиського району Тернопільської області; II дослід - у ТзОВ «Вітчизна», м. Конотоп Сумської області; III дослід - у ТзОВ «Промінь», с. Воєводське, Арбузинського району Миколаївської області; IV дослід - у ДП «Ілліч-Агро 
Донбас» м. Маріуполь, Маріупольського району Донецької області; V дослід -у ТОВ «МВК «Скатеринославський» с. Чумаків Дніпропетровського району Дніпропетровської області.

Дослід проводили на тільних коровах Голштинської породи віком 5 - 6 років. Утримувались тварини на прив'язі в типових корівниках. Годівля нормувалась відповідно до фізіологічного стану, продуктивності та маси тіла тварин. Напування централізоване. За проведеним клінічним оглядом тварин було відібрано у кожному господарстві по 10 тварин із клінічними проявами мікроелементозів та клінічно здорових. Матеріалом для досліджень слугувала сироватка крові тварин отримана у 5 тварин із кожної групи із яремної вени за 10 днів до отелення. В сироватці крові визначали вміст Йоду, Купруму, Мангану, Кобальту та Цинку методом атомно-абсорбційної спектрофотометрії в полум'яному режимі.

\section{Результати та їх обговорення}

Аналіз проведених досліджень свідчить, що вміст окремих мікроелементів у сироватці крові клінічно здорових тварин із різних біогеохімічних провінцій істотно різниться, однак, знаходиться у фізіологічних межах, хоча і подекуди на нижній іiі межі. Так, у ТзОВ «Україна» Тернопільської області вміст Йоду та Цинку в сироватці крові корів був на 2 - 23\% нижче відповідно до показників у інших дослідних господарствах. У сироватці крові тварин ТзОВ «Вітчизна» встановлено найнижчий вміст Купруму, Мангану та Кобальту. Грунти Північно-східних біогеохімічних провінцій очевидно більш насичені даними мікроелементами, що випливає із вищого їх вмісту у сироватці крові корів, однак, дані теж не однорідні. Так, у сироватці крові корів із ТОВ «МВК «Скатеринославський» (Дніпропетровська область) нижче вміст йоду та Купруму та Кобальту при вищому вмісті Цинку та Мангану у порівнянні із показниками тварин із ТзОВ «Промінь», та ДП «Ілліч-Агро Донбас» (III-IV дослід).

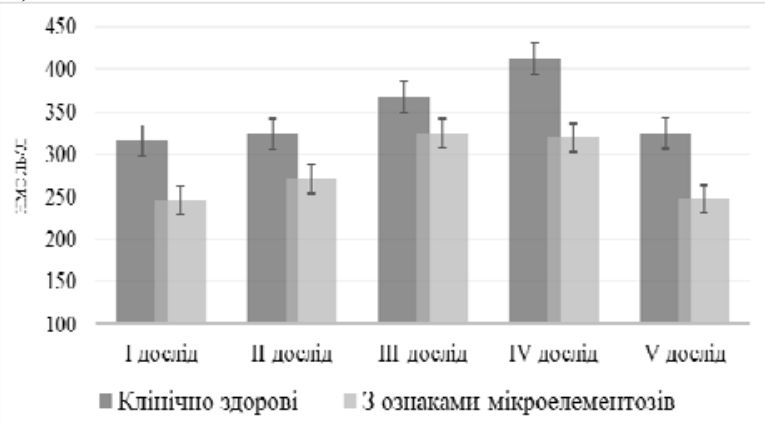

Рис. 1. Вміст Йоду у сироватці крові тільних корів нмоль/л $(\mathrm{M} \pm \mathbf{m}, \mathbf{n}=\mathbf{5})$

Встановлено істотне зниження вмісту Йоду в сироватці крові тварин з ознаками мікроелементозу на 16-24\% у корів всіх дослідних господарств. Однак, якщо у I, II та III досліді отримані данні вказують на зниження його вмісту до показника 246 - 271 ммоль/л (нижче фізіологічної норми) та у тварин яких досліджували у III та IV досліді хоча вміст даного металу і нижче 12 - 22\% ніж у клінічно здорових тварин із даних господарств, однак знаходиться у фізіологічних межах (319 - 325 ммоль/л).

Із літературних даних відомо, що вміст цинку в сироватці крові корів в нормі становить $15-23$ ммоль/л. Як видно із рисунку 2, навіть у клінічно здорових корів із дослідних господарств вміст даного металу в сироватці крові досить низький (14,8 17,4 ммоль/л). У тварин із ознаками мікроелементозів встановлено нижчий вміст Цинку в сироватці крові на $17-29 \%(\mathrm{p} \leq 0,05-0,01)$. При чому найнижчий вміст цинку в сироватці крові тварин господарства західного регіону.

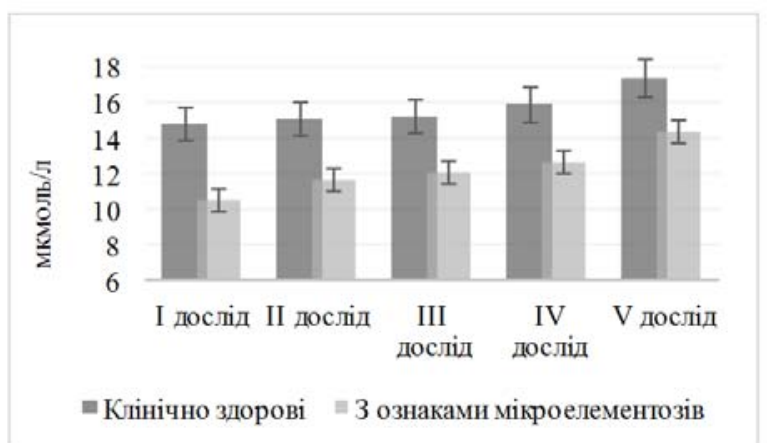

Рис. 2. Вміст Цинку у сироватці крові тільних корів мкмоль/л $(M \pm \mathbf{m}, \mathbf{n}=\mathbf{5})$

Вміст Купруму в сироватці крові клінічно здорових корів різних господарств достовірно не різниться, хоча і коливається в широких межах. Не залежно від біогеохімічної провінції за мікроелементозу корів вміст Купруму знижується до показника 8,3 12,5 мкмоль/л, що нижче на 22,6 - 41,1\% від показників здорових тварин. Слід однак відмітити, що лише у тварин із ДП «Ілліч-Агро Донбас» (IV дослід) вміст даного елементу хоча і нижче на 23 \% від показника здорових тварин, однак дане зниження недостовірне, а абсолютний показник вмісту - 12,5 $\pm 2,4$ ммоль/л не виходить за фізіологічні межі (12,5 - 22 ммоль/л).

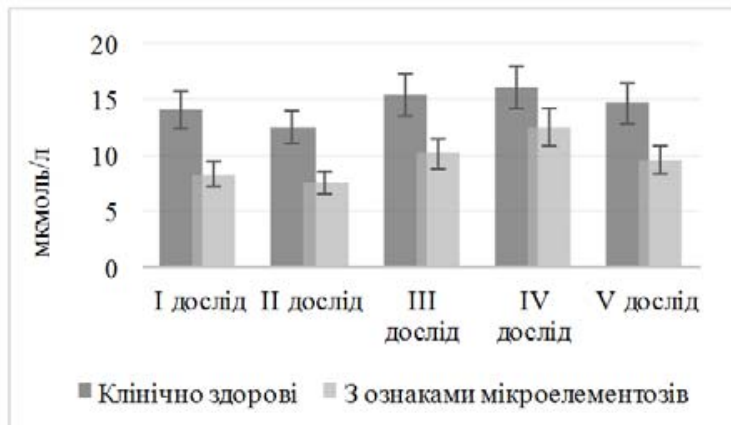

\section{Рис. 3. Вміст Купруму у сироватці крові тільних корів мкмоль/л $(\mathrm{M} \pm \mathbf{m}, \mathbf{n}=\mathbf{5})$}

Як видно із рис. 4, вміст Кобальту в сироватці крові корів 3 ознаками мікроелементозів істотно залежить від біогеохімічної провінції в якій перебуває господарство. Так, у тварин із господарств Північносхідних біогеохімічних провінцій (III-IV дослід) його вмісту у сироватці крові корів знаходиться у фізіологічних межах, хоча і нижче від показника здорових тварин. Так, у III досліді отримані данні вказують на 
нижчий вміст Кобальту у сироватці крові корів 3 ознаками мікроелементозів на $25,5 \%(\mathrm{p} \leq 0,05)$ у порівнянні із показником здорових тварин у даному господарстві, однак даний показник достовірно не різниться із показниками здорових тварин, що отримані у I та II досліді та знаходиться у фізіологічних межах.

Найнижчий вміст Кобальту в сироватці крові корів встановлено в господарствах ТзОВ «Україна» Тернопільської області та ТзОВ «Вітчизна» Сумської області. Навіть у клінічно здорових тварин вміст даного мікроелементу був в середньому на 18\% нижче від показника тварин що знаходились у господарствах північно-східних регіонів України (III-V дослід). У тварин $з$ клінічними проявами мікроелементозів вміст кобальту в сироватці крові був на 43 - 51\% нижче відповідно до такого у здорових тварин $(\mathrm{p} \leq 0,01)$.

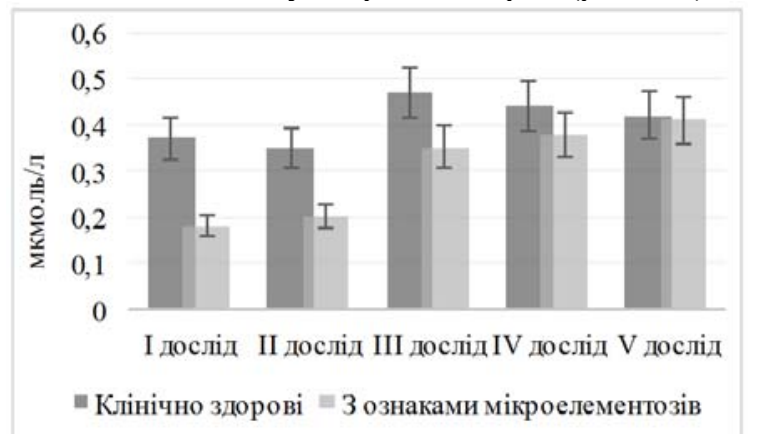

Рис. 4. Вміст Кобальту у сироватці крові тільних корів мкмоль/л $(\mathbf{M} \pm \mathbf{m}, \mathbf{n}=\mathbf{5})$

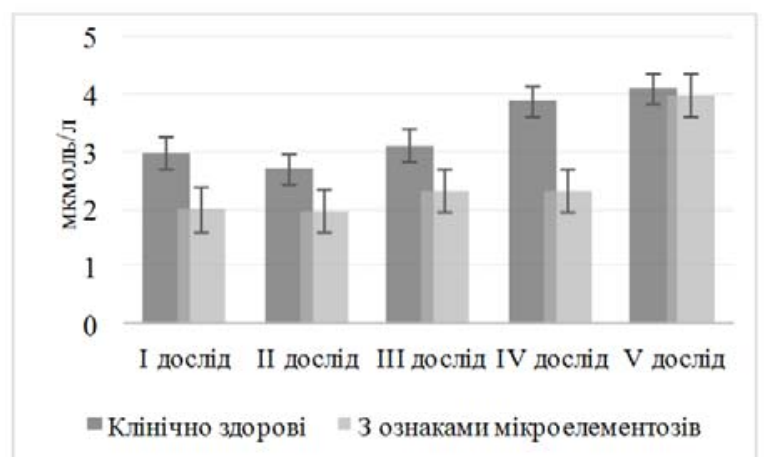

Рис. 5. Вміст Мангану у сироватці крові тільних корів мкмоль/л $(\mathrm{M} \pm \mathbf{m}, \mathbf{n}=\mathbf{5})$

Слід відмітити, що у клінічно здорових тварин із ТОВ «МВК «Скатеринославський» Дніпропетровської області (V дослід) вміст Мангану в сироватці крові $\epsilon$ найвищий $(4,10 \pm 0,15$ ммоль/л) і навіть у тварин із клінічними проявами мікроелементозів достовірно не змінюється (рис. 5).

У корів із клінічними ознаками мікроелементозів (I-IV дослід) вміст Мангану достовірно не різниться і знаходиться в межах 1,96 - 2,32 ммоль/л, що відповідно на $25-41 \%(\mathrm{p} \leq 0,01-0,001)$ нижче від показників клінічно здорових тварин у відповідних господарствах.

\section{Висновки}

Вміст окремих мікроелементів у сироватці крові клінічно здорових тільних корів із різних біогеохімічних провінцій істотно різниться, однак, знаходиться у фізіологічних межах. Встановлено достовірне зниження вмісту Йоду, Купруму, Мангану, Кобальту та Цинку в сироватці крові тварин з ознаками мікроелементозів різних біогеохімічних провінцій.

Перспективи подальших досліджень полягають у дослідженні вмісту мікроелементів в сироватці крові телят отриманих від клінічно здорових тварин та тварин із ознаками мікроелементозів та розробці методу корекції вмісту мікроелементів в сироватці крові корів та телят із урахуванням різних біогеохімічних провінцій.

\section{Бібліографічні посилання}

Klicenko, G.T., Kulyk, M.F., Kosenko, M.V., Lisovenko, V.T. (2001). Mineral'ne zhyvlennja tvaryn. K.: SVIT (in Ukrainian).

Avcyn, A.P., Zhavoronkov, A.A., Rish, M.A., Strochkova, L.S. (1991). Mikrojelementozi cheloveka: etiologija, klassifikacija, organopatologija. AMN SSSR. M.: Medicina (in Russian).

Levchenko V.I., Vlizlo V.V., Kondrahin I.P. (2002). Veterynarna klinichna biohimija. Bila Cerkva (in Ukrainian).

Sudakov, M.O., Bereza, V.I., Pogurs'kyj, I.P. (1991). Mikroelementozy sil's'kogospodars'kyh tvaryn. Za red. M.O. Sudakova. 2-e vyd. K.: Urozhaj (in Ukrainian).

Kondrahin, I.P. (1989). Alimentarnye i jendokrinnye bolezni zhivotnyh. M.: Agropromizdat (in Russian).

Georgievskij, V.I., Annenkov, B.N., Samohin, V.T. (1979). Mineral'noe pitanie zhivotnyh. M. (in Russian).

Стаття надійшла до редакиї 5.09.2016 